\title{
La variabilité des pratiques techniques comme indicateur sociologique dans les Hautes Corbières viticoles (Aude)
}

Georges Guille-Escuret

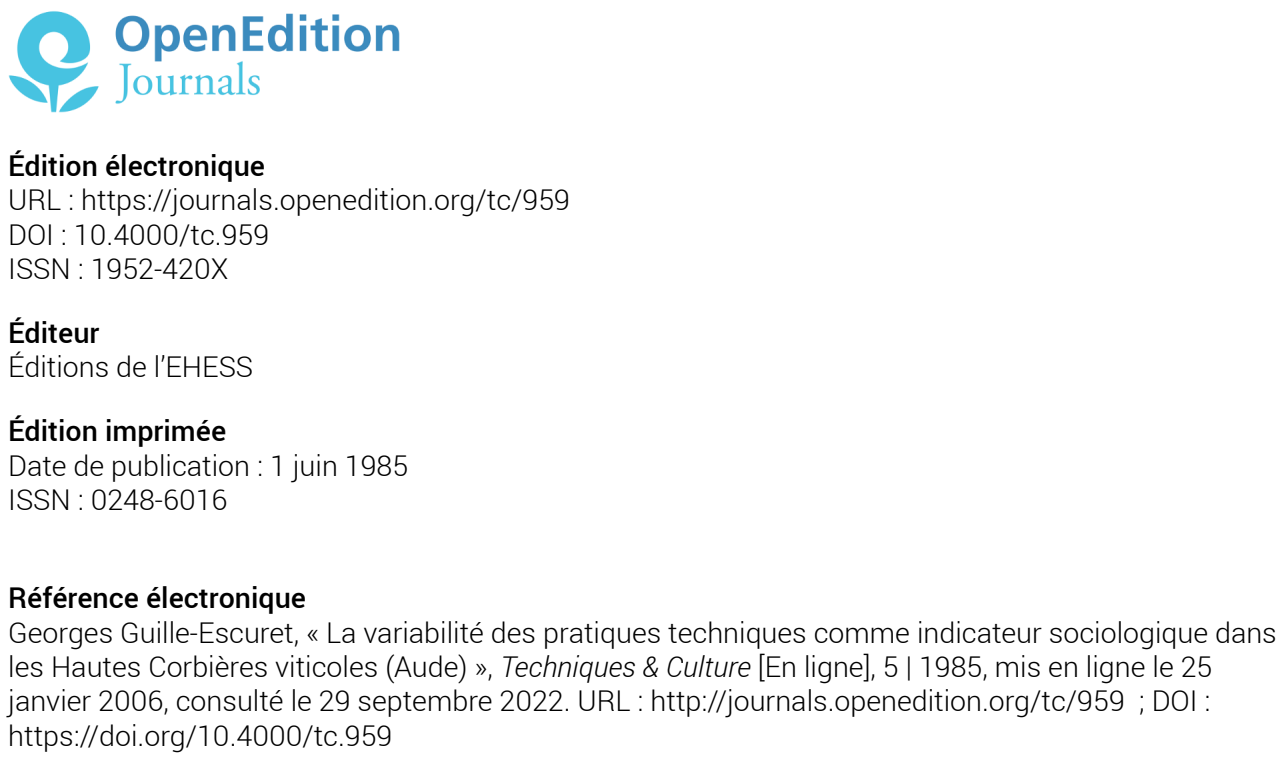

Ce document a été généré automatiquement le 29 septembre 2022.

Tous droits réservés 
La variabilité des pratiques techniques comme indicateur sociologique dans les Hautes Corbières viticoles (Aude)

Georges Guille-Escuret 